\title{
Differential effects of grazing by white sea urchins on recruitment of brown algae
}

\author{
T. A. Dean*, F. R. Jacobsen, K. Thies, S. L. Lagos \\ Marine Science Institute, University of California, Santa Barbara, California 93106, USA
}

\begin{abstract}
Experiments examined the effects of grazing by the white sea urchin Lytechinus anamesus, on microscopic life stages of laminarian algae and on newly recruited Cystoseira osmundacea in a Southem California kelp forest. Urchin exclusion experiments and culturing of cobbles from areas with and without urchins indicated that $L$. anamesus inhibited recruitment of laminarian algae by killing gametophyte or microscopic sporophyte life-stages. Newly recruited $C$. osmundacea were less affected and were able to survive in areas where white urchins were abundant. The differential effect of grazing by $L$. anamesus on these algae may lead to the exclusion of kelp by $C$. osmundacea, and may have a profound effect on eventual community composition regardless of the fate of urchins.
\end{abstract}

Grazing by sea urchins is a major structuring force in subtidal algal communities worldwide (see reviews by Lawrence 1975, Dayton 1985, Schiel \& Foster 1986, Harrold \& Pearse 1987). The most conspicuous effects of urchins occur when large mobile aggregations graze stands of adult macroalgae and cause abrupt changes in community composition. This results in the formation of so-called 'barren grounds', large expanses of hard substrata with few macroalgae. Scattered populations of urchins may remain in barren grounds eating drift from nearby kelp forests and microflora. As a result of the latter, barren grounds can persist for years as new algal recruits are grazed before they can reach adult size.

In the giant kelp Macrocystis pyrifera forests of Southern California there are 3 dominant urchin species: red urchins Strongylocentrotus franciscanus, purple urchins Strongylocentrotus purpuratus and white urchins Lytechinus anamesus (Leighton 1971). Red and purple urchins have received the greatest attention with regard to their effects on kelp (Leighton 1971, Dayton et al. 1984, Ebeling et al. 1985). However,

- Present address: Coastal Resources Associates, 531 Encinitas Blyd, Suite 119, Encinitas, California 92024, USA

(c) Inter-Research/Printed in F. R. Germany recent studies indicate that grazing by smaller $(\sim 1 \mathrm{~cm}$ test diameter) but abundant white urchins may be very important in some kelp forests, especially with respect to grazing on juvenile life-stages (Dean et al. 1984).

This investigation of the effects of grazing by Lytechinus anamesus was prompted by several observations in the San Onofre kelp forest, $22 \mathrm{~km}$ northwest of Oceanside, California, USA $\left(33^{\circ} 225^{\prime} \mathrm{N}, 117^{\circ} 32.5^{\prime} \mathrm{W}\right)$. In 1983-1984, we noted few visible recruits of $\mathrm{MaC}$ rocystis pyrifera or other laminarian algae on cobble substrata with high densities of $L$. anamesus. This suggested that white urchins were inhibiting recruitment of kelp by grazing smaller, microscopic life-stages. Also, we observed heavy recruitment of Cystoseira osmundacea in offshore portions (depths of 13 to $14 \mathrm{~m}$ ) of the San Onofre kelp forest in 1984-1985 and unlike M. pyrifera, C. osmundacea recruited in areas where white urchins were abundant. The latter observations suggested that $C$. osmundacea was less affected by grazing by white urchins than laminarian algae. Preferential feeding by urchins on algal species has been documented elsewhere (Leighton 1966, Vadas 1977) and such interactions have been shown to effect the distribution of algae (Vadas 1977, Lubchenco 1978, Sousa et al. 1981). Therefore, we tested the effects of L. anamesus on recruitment of small life-stages of laminarian algae and on the survival of newly recruited C. osmundacea.

Six stations were established in the San Onofre kelp forest in areas where Lytechinus anamesus were abundant: 3 in the northwest portion of the kelp forest and 3 in the southeast portion. These sites were located off of permanently marked transects that have been used since 1978 to monitor abundances of kelp and sea urchins (Dean et al. 1984). At each site, we erected fenced enclosures designed to exclude urchins. Each fence enclosed an area of $1 \mathrm{~m}^{2}$. Plastic screening (Vexar), with a mesh size of $7 \mathrm{~mm}$, was attached to a 
steel reinforcement bar frame and the frame was secured to the bottom with chain and T-shaped reinforcement bars. To prevent urchins from crawling over the fences, a lip made of sections of $10 \mathrm{~cm}$ PVC pipe cut longitudinally was secured to the top of the frame with plastic cable ties. The fences were paired with partially fenced controls at each site. The controls were identical to the fences described above except that the Vexar screen sides were cut off $10 \mathrm{~cm}$ above the substrata to allow urchins to crawl freely underneath the fences. The fenced and control pairs were $5 \mathrm{~m}$ apart.

The number of Lytechinus anamesus, laminarian algae, and Cystoseira osmundacea were counted after fences were erected on 2 April 1985. There were no other urchin species present. We then removed all white urchins from the exclusion areas and from a $1 \mathrm{~m}$ perimeter outside the fences. Twice weekly thereafter, through 31 May 1985, we visited each site and removed any urchins that had gotten into the cages (usually 1 to 6 individuals) and again cleared the area within a $1 \mathrm{~m}$ perimeter of the cages.

On 31 May 1985, we counted the number of Lytechinus anamesus, laminarian algae, and Cystoseira osmundacea within each exclusion and control plot. This was after the last clearing of urchins from the exclusion fences on 27 May 1985. We classified laminarian blades as such because Macrocystis pyrifera were indistinguishable from Pterygophora californica and other laminarian algae at this early stage of development. Later surveys at these sites indicated that all recognizable survivors were $M$. pyrifera.

Differences in the net change in densities of sea urchins and algae at test and control sites were examined using paired $t$-tests (Sokal \& Rohlf 1969). In all cases, densities were log-transformed (log [density +1$]$ ).

There was a significant change in densities of Lytechinus anamesus among fenced and control areas as a result of the exclusion of urchins. Densities of L. anamesus ranged from 59.5 to $30.8 \mathrm{~m}^{-2}$ in fenced and control plots in our initial survey of 2 April 1985 (Table 1). Eight wk later, white urchin densities averaged $2.7 \mathrm{~m}^{-2}$ in the exclusion and $56.0 \mathrm{~m}^{-2}$ in the control area
There were no visible laminarian algae in any of our plots on 2 April, but after 6 weeks small blade stages began to appear in the urchin exclusion areas. After $8 w k$, densities of blades in the $1 \mathrm{~m}^{2}$ fenced areas averaged $12.3 \mathrm{~m}^{-2}$ compared with $1.8 \mathrm{~m}^{-2}$ in the control. The increase in density was significantly greater in the exclusion area than in the controls (Table 1).

In contrast to the laminarian algae, changes in densities of Cystoseira osmundacea did not differ significantly among urchin exclusion and control plots (Table 1). However, mean densities decreased slightly in the control area and increased slightly in the exclusion sites, suggesting a possible effect of grazing by urchins.

We further examined the effects of grazing on microscopic life-stages of kelp by collecting cobble substrata from areas with high densities of Lytechinus anamesus ( $>10 \mathrm{~m}^{-2}$ ) and from nearby 'control' areas without urchins. These cobbles were cultured in the laboratory for $3 \mathrm{wk}$ to determine the number of gametophyte or microscopic sporophyte stages present. Three cobbles were collected from the downcoast (southeast) portion of the kelp forest where white urchins were abundant and 5 cobbles were collected from a control site ca $15 \mathrm{~m}$ away where there were no urchins. Both sets were collected from within $1 \mathrm{~m}$ of a adult Macrocystis pyrifera that had sporophylls with sori present, and that were presumably fertile.

The cobbles were placed in plastic buckets, covered, and brought to the surface. In the laboratory, cobbles were placed in filtered seawater containing $\mathrm{GeO}_{2}(1 \mu \mathrm{g}$ $\left.1^{-1}\right)$ overnight to prevent diatom contamination. The next day, the cobbles were placed in plastic culture containers with $8 \mathrm{l}$ of Provasoli's enriched seawater

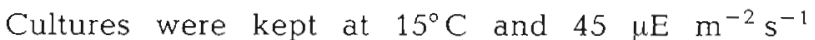
irradiance levels $(12 \mathrm{~h}$ photoperiod). These represent optimum conditions under which settled gametophytes develop into sporophytes within 10 to $21 \mathrm{~d}$ (Deysher \& Dean 1986). After $3 \mathrm{wk}$ in culture, the cobbles were examined under a dissecting microscope and the number of laminarian sporophytes were counted. The perimeter of each cobble was then traced and the surface area determined using a planimeter. Student's

Table 1. Mean densities (no. $\mathrm{m}^{-2}$ ) and net change in densities of Lytechinus anamesus, laminarian blades, and newly recruited Cystoseira osmundacea in urchin exclusion and control areas. 'Before' means were from a sampling prior to the removal of urchins and 'after' means were from a sampling at the conclusion of the experiment 8 wk later

\begin{tabular}{|lcccrrrrrr} 
& \multicolumn{3}{c}{ Mean before } & \multicolumn{2}{c}{ Mean after } & \multicolumn{3}{c}{ Net change } \\
& Excl. & Contr & Excl. & Contr & Excl. & Contr. & Paired $t$ & df & $p$ \\
\hline Lytechinus anamesus & 59.5 & 30.8 & 2.7 & 56.0 & -56.8 & +25.2 & -9.70 & 5 & $<0.01$ \\
Laminarian blades & 0 & 0 & 12.3 & 1.8 & +12.3 & +1.8 & -2.66 & 5 & 0.04 \\
Cystoseira osmundacea & 13.3 & 8.5 & 18.0 & 7.0 & +4.7 & -1.5 & -2.39 & 5 & 0.06 \\
\hline
\end{tabular}


t-tests (Sokal \& Rohlf 1996) were used to compare densities of sporophytes on cultured cobbles collected from urchin areas and from control sites.

Cobbles collected from areas with high densities of Lytechinus anamesus produced average sporophyte densities of 11 per $100 \mathrm{~cm}^{2}$ after $3 \mathrm{wk}$ in culture. This was significantly fewer than the 118 per $100 \mathrm{~cm}^{2}$ on cobbles collected from a nearby site without urchins $(t=-3.26, \mathrm{df}=6, p=0.02)$.

The results of these experiments indicated that Lytechinus anamesus inhibited recruitment of laminarians by killing small sporophyte or gametophyte lifestages. Whether urchins were actively grazing laminarian sporophytes is in question. It seems likely that the urchins were grazing on the microflora of which small laminarian life-stages were a part. It may also be that many of the laminarians were abraded as the urchins moved across the substratum.

Unlike the laminarian algae, small Cystoseira osmundacea appeared to be relatively unaffected by white urchins. We observed urchins crawling over the small C. osmundacea and some fronds showed signs of being grazed. However, this did not have a significant effect on abundances of $C$. osmundacea, at least for the 8 wk experimental period.

Most of the Cystoseira osmundacea in our experimental plots were less than $10 \mathrm{~cm}$ in height at the outset of our study, and from the observations of Schiel (1985), we suspect that these individuals were recruited during the previous 2 to 3 mo. Thus, experiments were not conducted during a time when most C. osmundacea were developing from microscopic embryonic stages. However, new recruits were observed at one site where Lytechinus anamesus had persisted in high densities since 1978 (Dean et al. 1984, S. Schroeter \& J. Dixon unpubl.) indicating that embryos developed and survived for several months where there were urchins.

Recruitment of Cystoseira osmundacea at depths greater than $10 \mathrm{~m}$ is unusual. Previous studies in the San Onofre kelp forest (T. A. Dean unpubl.) and elsewhere (Schiel 1985) indicate that C. osmundacea is seldom found at high densities $\left(>1 \mathrm{~m}^{-2}\right.$ ) at depths greater than 10 or $11 \mathrm{~m}$. The recruitment of C. osmundacea in deeper parts of the San Onofre Kelp forest began in mid-1984, coincident with the El Nino of 1983 to 1984 , and may have been the result of thinning of the Macrocystis pyrifera canopy, and increased water clarity that occurred during this time (Dean \& Jacobsen 1986, Tegner \& Dayton 1987). This extension of $C$. osmundacea into deeper waters plus the differential effect of grazing by Lytechinus anamesus on C. osmundacea and laminarian algae may have profound effects on future community composition. If C. osmundacea are able to escape grazing pressures of urchins, they may eventually dominate the community to the exclusion of laminarians such as $M$. pyrifera and Pterygophora californica. Established stands of $C$. osmundacea are resistant to invasion by laminarians (Dayton et al. 1984) and adult C. osmundacea have low rates of mortality (Dayton et al. 1984, Schiel 1985, Gunnill 1986). Thus, the effect of grazing on early life-stages may have a long-lasting influence on the community regardless of eventual changes in the abundance of white urchins

Acknowledgements. We thank Dennis Jung for assisting in the field work. Larry Deysher, Steve Schroeter, and John Dixon kindly read an earlier draft of this manuscript. This research was funded by the Marine Review Committee. Inc. (MRC), but the MRC does not necessarily agree with the results or conclusion herein.

\section{LITERATURE CITED}

Dayton, P. K. (1985). Ecology of kelp communities. Ann. Rev. Ecol. Syst. 16: 215-245

Dayton, P. K., Currie, V., Gerrodette, T., Keller, B., Rosenthal, R. Tresca, D. V (1984). Patch dynamics and stability of California kelp communities. Ecol. Monogr. 54 (3): 253-289

Dean, T A., Jacobser, F. R. (1986). Nutrient-limited growth of juvenile kelp, Marcocystis pyrifera during the 1982-84 'El Niño' in southern California. Mar. Biol 90: 597-601

Dean, T A., Schroeter, S. C., Dixon, J. D. (1984). Effects of grazing by two species of sea urchins (Strongylocentrotus franciscanus and Lytechinus anamesus) on recruitment and survival of two species of kelp (Macrocystis pyrifera and Pterygophora californica). Mar. Biol. 78: 301-313

Deysher, L. E., Dean, T A. (1986). Interactive effects of light and temperature on sporophyte production in the giant kelp, Macrocystis pyrifera. Mar Biol. 93: 17-20

Ebeling, A. W., Laur, D. R., Rowley, R. J. (1985). Severe storm disturbances and reversal of community structure in a southern California kelp forest. Mar. Biol. 84: 287-294

Gunnill, F. J. (1986). Demography of Cystoseira osmundacea and Halidrys dioica (Phaeophyta, Cystoseiraceae) at La Jolla, California, USA. Botanica mar. 29: 137-146

Harrold, C., Pearse, J. (1987). The ecological role of echinoderms in kelp forests. In: Jangoux, M., Lawrence, J M. (eds.) Echinoderm studies, Vol. 2. A A. Belkema, Rotterdam, p. 137-233

Lawrence, J. M. (1975). On the relationship between marine plants and sea urchins. Oceanogr. mar. Biol. A. Rev. 13: 213-286

Leighton, D. L. (1966). Studies of food preference in algivorous invertebrates of Southern California kelp beds. Pacif Sci. 20: $104-113$

Leighton, D. L. (1971). Grazing activities of benthic invertebrates in Southern California kelp beds. In: North, W. J. (ed.) The biology of giant kelp beds (Macrocystis) in California. Nova Hedwegia 32 (Suppl.): 421-453

Lubchenco, J. (1978). Plant species diversity in a marine intertidal community: importance of herbivore food preference and algal competitive abilities. Am. Nat. 112: 23-39 
Schiel, D. R. (1985). A short-term demographic study of Cystoseira osmundacea (Fucales: Cystoseraceae) in Central C.rilifornia. J. Phycol. 21: 99-106

Schiel, D. R., Foster, M. S. (1986). The structure of subtidal aigal stands in temperate waters. Oceanogr mar. Biol. A. Rev. 24: 265-307

Sokal, R. R., Rohlf, F. J. (1969). Biometry. The principles and practice of statistics in biological research. It $\mathrm{H}$. Freeman and Co., San Francisco
Sousa, W. P., Schroeter, S. C., Gaines, S. D. (1981). Latitudinal variation in intertidal algal community structure: the influence of grazing and vegetative propagation. Oecologia (Berl.) 48: 297-307

Tegner, M. J., Dayton, P. K. (1987). El Niño effects on Southern California kelp forest communities. Adv ecol. Res. 17: $243-279$

Vadas, R. L. (1977). Preferential feeding: an optimi ation strategy in sea urchins. Ecol. Monogr. 47. 337-374

This note was presented by Professor N. D. Holland; it was accepted for printing on July 6, 1988 